OPEN ACCESS

Approved by: Frontiers Editorial Office, Frontiers Media SA, Switzerland

${ }^{*}$ Correspondence: Frontiers Production Office production.office@frontiersin.org

Specialty section:

This article was submitted to Immunological Tolerance and Regulation, a section of the journal Frontiers in Immunology

Received: 10 December 2021 Accepted: 10 December 2021 Published: 24 December 2021

Citation: Frontiers Production Office (2021) Erratum: Immunoregulatory Effects of Myeloid-Derived Suppressor Cell

Exosomes in Mouse Model of Autoimmune Alopecia Areata.

Front. Immunol. 12:832980. doi: 10.3389/fimmu.2021.832980

\section{Erratum: Immunoregulatory Effects of Myeloid-Derived Suppressor Cell Exosomes in Mouse Model of Autoimmune Alopecia Areata}

\author{
Frontiers Production Office* \\ Frontiers Media SA, Lausanne, Switzerland
}

Keywords: myeloid-derived suppressor cells, exosomes, alopecia areata, therapy, regulatory T cells

\section{An erratum on:}

Immunoregulatory Effects of Myeloid-Derived Suppressor Cell Exosomes in Mouse Model of Autoimmune Alopecia Areata

by Zöller M, Zhao K, Kutlu NN, Bauer N, Provaznik J, Hackert T and Schnölzer M (2018). Front. Immunol. 9:1279. doi: 10.3389/fimmu.2018.01279

Due to a production error, an author name was incorrectly spelled as "Natalia Kutlu". The correct spelling is "N. Natali Kutlu". The publisher apologizes for this mistake.

The original version of this article has been updated.

Copyright $(2021$ Frontiers Production Office. This is an open-access article distributed under the terms of the Creative Commons Attribution License (CC BY). The use, distribution or reproduction in other forums is permitted, provided the original author(s) and the copyright owner(s) are credited and that the original publication in this journal is cited, in accordance with accepted academic practice. No use, distribution or reproduction is permitted which does not comply with these terms. 